\title{
The influence of climate change on the market value of coastal residential property in South Africa
}

\author{
A. Kruger \\ Department of Finance and Investment Management, \\ University of Johannesburg, South Africa
}

\begin{abstract}
The emerging nature of climate change and events associated with climate change raises the question of to what extent and how the changing climate will affect the well-established property valuation processes and procedures. Events like the one in March 2007, when the KwaZulu-Natal coast was hit by storm swells which severely damaged coastal properties, is a typical example. The economic loss was estimated to be more than one billion rand. Risk associated with the changing climate is on the increase and if the number of studies (nationally and globally) regarding this phenomenon is taken into account, then there is a need to quantify this risk. In these national and global studies, a variety of concepts, unrelated to market value or a manipulated form of market value, are used to quantify economic loss. However, financial decisions regarding property, plant and equipment are made based on the concept of market value (market value $=$ fair value). This raises the question that this study will attempt to answer: How should property valuers change their current practice of investigating past market behaviour to arrive at an opinion of market value to also include climate change risk? This study aims to identify the knowledge, perceptions and practices of property valuers in a particular property market, on the Southern Cape coast, South Africa regarding the predicted rise in sea level. The paper will attempt to construct an instrument property that valuers can use to determine the market value of coastal residential properties. The Southern Cape coast was chosen because it was identified in two separate studies conducted in 1993 and 2010 as the stretch of coastline along the South African coast most vulnerable to a rise in sea level. Keywords: climate change, rising sea level, market value, residential property, coastal property, risk, immovable property.
\end{abstract}




\section{Introduction}

Property valuers evaluate past market behaviour, to develop an opinion of market value (Armitage and Skitmore [1]). Events like Hurricane Katrina, which hit New Orleans, USA in 2005 and the storm swell on the KwaZulu-Natal coast, South Africa in March 2007 can severely damage coastal properties. The damage caused by the KwaZulu-Natal storm swell was estimated to be more than one billion rand (Smith et al. [2]). In 1992, Hughes conducted a study in which the impact of sea level rise on the South African coastal environment was researched (Hughes [3]). In the study he found that the Southern Cape coast was vulnerable to storm events similar to the storm swell on the KwaZulu-Natal coast in March 2007 (Hughes [3]). He also pinpointed Knysna and Sedgefield as the most likely places for similar storm events to occur (Hughes [3]). Hughes's findings were confirmed by several South African studies such as those of Smith et al. [2], Cartwright [4], Brundrit [5], Blake [6], Blake and Chimboza [7] and Blake [8].

A temporary decline in selling prices after storms and the unpredictability of such events create a problem for property valuers who rely on historic data and economic trends to estimate the market value of immovable property (Beracha [9]). This is further complicated by the reality that the impact of climate change is modelled on what might happen in the future, either in the short or long-term. In response to climate change the South African Government has promulgated the National Environmental Management: Integrated Coastal Management Act No. 24 of 2008. The purpose of the Act is to mitigate the potential impact of a rise in sea level along the South African coast (South Africa [10]). This legislation compels provinces and local authorities to delineated coastal set-back lines to support improved planning and management of vulnerable coastal areas (South Africa [10]). Currently provinces and local authorities are busy with the delineation process and it is thus difficult to estimate the cost of these mitigating measures. Property valuers therefore cannot rely on past market behaviour regarding climate change to provide a necessary perspective for the future. The slow onset nature of climate change thus raises the question, to what extent and how the well-established valuation processes and procedures will be affected by climate change.

Although much research has been done on climate change and the impact thereof on the environment, very little research has been done regarding the effect of climate change on the market value of immovable property. Research on the effect of climate change within the property valuation fraternity is directed at sustainability issues (De Francesco and Levy [11], Lützkendorf [12], Austin [13] and Warren-Myers [14] amongst others). Only one study was found that commented on the effect of climate change on the market value of residential coastal property (Bienert et al. [15]). However, within other disciplines there are several studies in which an attempt was made to quantify the potential risk of climate change to immovable property in monetary terms. In two of these studies (Hennecke et al. [16] and Cartwright [4]), the value of land was based on the average value for land in an entire suburb and no distinction was made with regard 
to the location of such properties, for example sea front or inland properties. This is contrary to valuation theory and standard valuation practice.

Models to Evaluate the Quantitative Effects of Climate Change on Real Estate Markets is the first study in which researchers drew a direct link between climate change and the predicted effect thereof on the market value of immovable property (Bienert et al. [15]). They clearly stated that “... today's value of land is always the current value of future profit potentials which can result thereof. If this future profit is restricted due to climate change, it has to be considered in today's value" (Bienert et al. [15]). Although Bienert et al. [15] drew the valuation fraternities' attention to the impact of climate change on the market value of immovable property no follow up studies were conducted.

\section{Problem statement}

"The economic concept of value is not inherent in the commodity..." but "... is created in the minds of individuals who make up the market" - according to the Appraisal of Real Estate [17]. Property valuers are employed to interpret and analyse the property market in an attempt to estimate and develop an opinion of the market value of fixed property (Betts and Ely [18]). Property valuers rely on information from the past to arrive at an opinion of value at the date of valuation. According to Ratcliff “... only recent transactions can be used in the analysis of recent market behaviour, and the forecast is as of today or the near future" (Ratcliff [19]). He expands his observation when he refers to valuation instructions that call for long-range future perspectives, "These long-range forecasts require a longrange market analysis that evaluates past market behaviour over a long enough history to provide the necessary perspective for prophecy" (Ratcliff [19]).

Due to the slow onset nature of climate change there are no past market behaviour on which property valuers can base their market analysis. This raises the question of how and to what extent climate change, specifically rising sea levels, will affect the well-established valuation processes and procedures. Measuring the impact of climate change relies on predictions of what might happen in the future, either in the short or long-term. Property valuers can, therefore, not rely on the past to provide the necessary perspective for prophecy referred to by Ratcliff [19] when they deal with a rise in sea level. Another impediment is raised by Bienert et al. [15] when they state that a restriction of future profits must be considered in today's value.

The problem is that property valuers will have to take the extent of the detrimental effect and associated risks of the rising sea level into account when they receive an instruction to determine the market value of residential coastal properties. At present property valuers do not have a basis to determine the risk of long-term changes like a rise in sea level on an investment in residential coastal properties. 


\section{Research question}

The aim of the research is to investigate the behaviour of property valuers in the residential coastal market of Sedgefield with regard to the predicted effect and ensuing risk of a rise in sea level in their valuations. In order to acquire an understanding of how property valuers deal with climate change risk in practice.

Getting a better understanding of how property valuers respond to the emerging nature of climate change will be an important insight in understanding the property market of the future in Sedgefield. In order to achieve the aim, answers will be pursued by asking the following research question and objectives.

The central question that will guide the research is: To what extent does the predicted rise in sea level and ensuing risk thereof affect property valuer's behaviour in the residential coastal market in Sedgefield and how will this influence valuation practices in South Africa?

The following objectives will be pursued:

a. To establish the knowledge and attitudes towards the consequential risk of a rise in sea level on property valuers practicing in Sedgefield's property market;

b. To ascertain if and how property valuers use their knowledge of the rising sea level when they explore the property market in Sedgefield;

c. To investigate the behaviour of property valuers in their adaption and mitigation for the anticipated rise in sea level; and

d. To use sales data from the property market in Sedgefield to establish if the knowledge, attitudes and behaviour of property valuers are reflected in current market behaviour.

\section{Literature review}

The emerging nature of climate change raises the question of how and to what extent climate change will affect valuation theory. According to Kummerow [20] valuation theory consist of four components: 1) Value equals discounted expected future benefits of ownership; 2) Value is proportional to expected utility of various property characteristics; 3) Prices are revealed in market transactions; and 4) Prices tend to adjust towards equilibrium where supply and demand would be in balance and prices unchanging, but this process takes time and markets are normally not at equilibrium (Kummerow [20]).

Property valuers therefore look at past market behaviour, to develop an opinion of market value. Measuring the impact of climate change relies on predictions of what might happen in the future, either in the short or long-term. Consequently property valuers cannot rely on past market behaviour regarding climate change to provide the necessary perspective for prophecy referred to by Ratcliff [19]. According to Rudman [21] the changing climate is a reality that may have far reaching social, economic and environmental consequences. A result of the predicted increase in temperature of between 4 and $6.4^{\circ} \mathrm{C}$ by 2099 will be visible in changing weather and precipitation patterns as well as a rise in sea level of $0.59 \mathrm{~m}$ (Nicholls et al. [22]). 
The rise in sea level is the result of a thermal expansion of the oceans, melting of the ice caps and glaciers and an increase in the ice discharge from the ice sheets in Greenland and Antarctica (Nicholls et al. [22]). The IPCC's predictions of sea level rise were confirmed by a study of the South African tide gauge records over the past 30 years (Theron and Rossouw [23]). Theron and Rossouw's [23] study confirmed the findings of an earlier study conducted by Hughes [3] in which he found that the predicted rise in sea level will be accompanied by beach erosion, flooding and inundation, salt water intrusion and elevated coastal groundwater tables and storm damage .

In two South African coastal risk assessment studies an attempt was made to establish the impact of a rise in sea level and the associated hazards on the local economy. The first was a study conducted by Anton Cartwright in 2008 for the City of Cape Town with the primary aim "To model and understand the ramifications of predicted sea-level rise and increased storm events for the City of Cape Town, thereby providing information that may be used for future planning, preparedness and risk mitigation" (Cartwright [4]). In the study he refers to the diverse group of people and institutions who will be influenced by a rise in the sea-level and the distinctly different values they will place on the affected goods and services.

For example the owners of immovable property would like to know what it will cost to replace equipment and property lost in a sea-level rise event (Cartwright [4]). Cartwright explains that this is a common mistake often made in environmental risk analysis when replacement cost is equated to economic loss. He further declares that opportunity cost should be used when environmental damage is being assessed and that it is mostly less than financial costs (Cartwright [4]). In the study he quantifies the economic impact of sea-level rise by using the City's valuation roll as basis to determine a rate per square meter for coastal land. Based on his assumption he calculated the estimated economic loss of private property around the Cape Town coastline at "R3.2 billion for Scenario 1, R19.5 billion for Scenario 2 and R44.5 billion for Scenario 3" (Cartwright [4]).

Although the basis for the base line (City of Cape Town, Valuation Roll) used by Cartwright [4] is market value he altered the values by calculating averages and establishing weighted averages for land. This approach deviates from valuation theory according to which the final opinion of value should be expressed as a "range of values or single dollar figure derived from the reconciliation of value indications and stated in the appraisal report" (Appraisal of Real Estate [17]).

The second and latest study was conducted in 2010, commissioned by the Provincial Government of the Western Cape Department of Environmental Affairs and Development Planning: Strategic Environmental Management, with the aim of assessing the risk of sea level rise and flood hazards (Umvoto Africa [24]). According to Umvoto Africa "an extreme coastal event comparable to the KZN March 2007 storm could cause damage worth half the total annual budget of the Eden District Municipality and five coastal Local Municipalities combined" (Umvoto Africa [24]). There are no clear explanations of how they reached this assumption other than that it is based on the 2009/10 budget of the Eden District Municipality and the associated local municipalities of approximately R2, 
5 billion. Based on this figure they determined an economic vulnerability score expressed as a "percentage value of the budget increasing in factors of ten, ranging from $0.0004 \%$ of the total budget (R 1 million - score of 1 ) to $400 \%$ of the total budget (R 10 billion - score of 5)" (Umvoto Africa [24]).

The methodologies used in both these studies are not aligned to property valuation theory and methodology, which gives emphasis to market value. It was therefore decided to look at how international studies dealt with a similar situation. A number of studies were found: two in California, USA and one in Sydney, Australia.

In a paper by Heberger et al. [25] the replacement value of property are used to estimate the economic impact of sea-level rise. They acknowledge the difference between replacement cost and market value and indicated that market values are higher due to a number of site specific factors whilst replacement value is based on national-average construction costs (Heberger et al. [25]). According to the authors their analysis was restricted by the limitations related to economic valuation methodology. In their analysis of floods they used the replacement value of buildings and the content thereof to estimate the economic cost of a rise in sea level. It is clearly stated that they did not use the property or land value which are much higher; however, they do say that it should be used if the land is permanently inundated or abandoned. They further commented that replacement value cannot be used to estimate the cost of erosion as erosion is the result of the total loss of property and land. In conclusion they pointed out that a rough estimation of land values along the coast was made but additional studies are needed (Heberger et al. [25]).

In a second paper by King et al. [26] the assessed value was used to determine the economic cost of sea-level rise. The authors drew attention to the fact that data regarding function of age, but also character and condition of assets was not readily available and they therefore valued properties at risk to flooding and erosion using a constant depreciation factor of $25 \%$ (King et al. [26]). They also indicated that "Depreciated replacement values are appropriate for estimating damages to structures, yet the market value of land (which literally falls into the ocean, and cannot be replaced) is a more appropriate estimation to account for land damages associated with upland erosion" (King et al. [26]). A comment made namely that "The sales comparison approach is an ideal method to use when there are limited market sales but accessible data detailing various site characteristics for all properties" indicate that the authors of this paper are not familiar with the property valuation methodology at all, as the sale comparison approach relies on sales data to determine market value (King et al. [26]).

In an Australian study it is stated that "As the market value of a property is reflected in its land value, the land value can be used to determine the market value and, therefore, vulnerability" (Hennecke et al. [16]). Although they defined market value as land value plus the value of improvements, it seems as if they ignored the value of improvements and relied on land value alone to indicate market value (Hennecke et al. [16]). In Australia land value is used as the basis to determine assessment rates in contrast to South Africa where market value is used as the basis to determine assessment rates. 
All the studies mentioned above are in agreement that the predicted rise in sea level will result in an economic loss for coastal communities. In their attempts to identify the quantum of the economic loss a variety of methodologies were utilized. However, the well-defined valuation methodology, property valuers use to estimate and develop an opinion of the market value of fixed property was ignored (Betts and Ely [18]).

The impending problem created by the predicted rise in sea level will have to be considered by property valuers when they interpret and analyse the property market in their efforts to estimate and develop an opinion of the market value of residential coastal property. Property valuers will therefore in future have to consider predicted imminent events in their interpretation and analysis of a specific property market, contrary to Ratcliff's opinion that "... long-range forecasts require a long-range market analysis that evaluates past market behaviour over a long enough history to provide the necessary perspective for prophecy" (Ratcliff [19]). The methodologies used in the above-mentioned studies differs with the concept of 'market value' used by property valuers in accordance with the International Valuation Standards (International Valuation Standards Committee [27]) and 'fair value' as prescribed by International Financial Reporting Standards (International Accounting Standards Board [28]) as well as the Local Government: Municipal Property Rates Act, Act No. 6 of 2004 (South Africa [29]). According to International Valuation Standards, market value and fair value are as a general rule in agreement (International Valuation Standards Committee [27]).

Risk associated with the changing climate is on the increase and from the studies reviewed above there is a need to quantify this risk. In these studies a variety of concepts, not related to market value or a manipulated form of market value, was used in their attempts to quantify economic loss. This raises the question this study will attempt to address: How will property valuers change their current practice of looking at past market behaviour to arrive at an opinion of market value to also includes climate change risk which is a predicted future event? According to Ratcliff [19] a property valuer's primary aim is to understand how humans behave in a specific property market in order to develop reliable inputs. This study therefore aims to identify the knowledge, perceptions and practices of property valuers in the Sedgefield property market regarding the predicted rise in sea level.

\section{Research design and methodology}

The focus of the study is to understand and interpret the extent to which the predicted rise in sea level will affect the decisions made by property valuers in the residential coastal market in South Africa. The study will be conducted from the perspective of a property valuer in the Sedgefield property market. Market participants rely on property valuers to determine the market value of a property they may be interested in buying, selling, bonding, insuring or rating. Property valuers interpret the behaviour of market participants according to valuation 
theory to determine the market value of immovable property as at the date of valuation. Property valuers are pragmatists who are real-world practice orientated, problem-centred and attentive to the consequences of events or actions which influences a specific property market.

\subsection{Research design}

A mixed methods approach will be pursued by way of a sequential exploratory design, starting with an initial phase of qualitative data collection and analysis followed by a phase of quantitative data collection and analysis. Exploratory research is defined as "a methodological approach that is primarily concerned with discovery and with generating or building theory" (Jupp [30]).The purpose of this exploratory sequential design will be to develop an in-depth understanding of the phenomenon of a rise in sea level in order to develop an instrument that can be used by property valuers when they assess the market value of residential coastal property.

\subsubsection{Research population and area}

According to the South African Risk and Vulnerability Atlas (South Africa [31]), an increase in water temperature will lead to increase in sea levels. It also predicts that the changing climate may create storms of greater intensities which will affect coastal settlements. Although the research population is all the residential coastal properties along the South African coastline, Hughes [3] identified four particular areas, namely: Greater Cape Town (Melkbosstrand to Gordon's Bay); the South Cape coast (Mosselbay to Nature's Valley); Port Elizabeth; and the Natal South coast and Greater Durban (Southbroom to Ballitoville) as the area's most vulnerable to a rise in sea level. This was confirmed by Umvoto Africa [24] in a study commissioned by the Western Cape Provincial Government with regard to the climate change risk in the Eden District Local Authority. Sedgefield, a small coastal town halfway between George and Knysna, was indicated as the most vulnerable town in both studies.

This study will focus on residential coastal properties in Sedgefield. The purpose of the study is to understand and interpret the extent to which the predicted rise in sea level will affect the decisions made by property valuers in the residential coastal market in South Africa. Although Sedgefield will be used as a case study and it is generally accepted that the results of a case study cannot be generalized, property valuers will be able to use the results to assist them when they conduct valuations in other residential coastal areas along the South African coastline.

\subsection{Methodology}

The researcher followed an inductive approach to extract knowledge and perceptions from property valuers with an interest in residential coastal property, to discover if they are aware of the predicted rise in sea level and how they perceive this to impact on residential coastal properties. The second quantitative phase follows up on the qualitative phase for the purpose of determining if the valuer's views are reflected in market practices. 


\section{Phase 1}

Research instrument: Open-ended questions in structured interviews were used to collect data to determine property valuer's knowledge and perceptions regarding climate change and the inclusion thereof when they conduct valuations. According to Cooper and Schindler [32] structured interviews is reliable and valid as it assist the interviewer to remain neutral, allow for a direct comparability of responses and eliminated inconsistency in questions.

A purposive sample was drawn by inviting all registered professional and associated professional property valuers who may conduct valuations in Sedgefield to participate. Of the 44 registered property valuers, 13 property valuers were interviewed.

The 13 interviews were transcribed and the researcher used Atlas.ti to analyse the data collected. Atlas.ti provides software support in the course of data-analysis by assisting the researcher with the coding and annotating activities (Henning et al. [33]).

\section{Phase 2}

Research instrument: Secondary data, i.e. sales data for Sedgefield covering the last 20 years were sourced from the Deeds Office by means of the Property Intellect (a program providing access to the deeds office data) through the UJ library. The sales data were used to establish if market participants (i.e. buyers and sellers) behaviour are in agreement with the knowledge and attitudes of property valuers in the Sedgefield property market. The secondary data provided by Property Intellect are reliable and valid as it is obtained directly from the different Deeds Office's in South Africa. All property transactions are recorded by the deeds offices in accordance with the Deeds Registries Act 47 of 1937 as amended (South Africa [34]).

A nonprobability procedure was followed to draw a sample of properties in Sedgefield. Although a nonprobability sample is arbitrary and subjective according to Cooper and Schindler [32], this was deliberately done as only properties sold more than once in the last 20 years were needed to establish trends.

The data were analysed in Excel to establish trends in sales prices and to determine the relationship between prices and rising sea levels. This was done by identifying any irregularities in prices shortly after events that may have been contributed to a rise in mean sea level.

\section{Preliminary conclusion}

Sedgefield is a small town situated on the Swartvlei estuary on the Southern Cape coast in South Africa. Sedgefield was identified by Hughes [3] as the urban area most likely to be affected by a rise in sea level in South Africa. The business district and approximately $40 \%$ of the residential areas are below five metres above the current mean sea level.

The preliminary conclusion indicates that although the majority of the property valuers interviewed are aware of climate change their knowledge regarding climate change is very general in nature. They are also not concerned about the 
predicted rise in sea level and unaware of the National Environmental Management: Integrated Coastal Management Act No. 24 of 2008 and the impact thereof. They all indicated that they still look at past market behaviour to determine market value of coastal residential property and are of the opinion that the rise in sea level should not be considered at all.

The property valuer's behaviour (looking at past sales) was observed in phase two. The analysis of the quantitative data indicated a steady increase in market value of properties sold twice and more over the last 20 years. This applied to all sales which include all properties situated just above mean sea level as well as properties flooded in the past.

The preliminary conclusion is that although property valuers are aware of climate change and the predicted rise in sea level, they do not know how to take it into account and therefore ignore the predicted rise in sea level in favour of the historic data they are used to. The researcher believes that one's he has completed the planned instrument it will provide property valuer's a methodology to follow.

\section{References}

[1] Armitage, L. \& Skitmore, R.M., Property market analysis in the valuation process: a Survey of Australian practice. Pacific Rim Property Research Journal, 9(4), pp. 330-347, 2003.

[2] Smith, A., Guastella, L., Bundy, S. \& Mather, A., Combined marine storm and saros spring high tide erosion events along the KwaZulu-Natal coast in March 2007. South African Journal of Science, 103(July/August), pp. 274276, 2007.

[3] Hughes, P., The impacts of sea level rise on the South African coastal environment. Unpublished PhD Thesis ed. Cape Town: University of Cape Town, 1992.

[4] Cartwright, A., Global climate change and adaptation - sea-level rise risk assessment. Phase 4: Sea-level rise adaptation and risk mitigation measures for the City of Cape Town, 2008.

[5] Brundrit, G., Global climate change and adaptation - a sea-level rise risk assessment. Phase 5: Full investigation of longshore features of vulnerability on the City of Cape Town coastline, and their incorporation into the City of Cape Town Geographic Information System, 2009.

[6] Blake, D., Phase 1 Report: Eden District Municipality Sea level Rise and Flood Risk Literature Review, Cape Town: Provincial Government of the Western Cape Department of Environmental Affairs and Development Planning: Strategic Environmental Management, 2010.

[7] Blake, D. \& Chimboza, N., Phase 2 report: Eden District Municipality Sea Level Rise and Flood Risk Modelling, Cape Town: Provincial Government of the Western Cape Department of Environmental Affairs and Development Planning: Strategic Environmental Management, 2010.

[8] Blake, D., Phase 3 Report: Eden District Municipality Sea Level Rise and Flood Hazard Risk Assessment, Cape Town: Provincial Government of the 
Western Cape Department of Environmental Affairs and Development Planning: Strategic Environmental Management, 2010.

[9] Beracha, E.P.R., How major hurricanes impact housing prices and transaction volume. Real Estate Issues, 33(1), pp. 45-57, 2008.

[10] South Africa, Act 24 of 2008: National Environmental Management: Integrated Coastal Management Act. Pretoria: Government Printer, 2008.

[11] De Francesco, A.J. \& Levy, D., The impact of sustainability on the investment environment. Journal of European Real Estate Research, 1(1), pp. 72-87, 2008.

[12] Lützkendorf, D.L.T., Sustainability in property valuation: theory and practice. Journal of Property Investment \& Finance, 26(6), pp. 482-521, 2008.

[13] Austin, G., Sustainability and income-producing property valuation: North American status and recommended procedures. Journal of Sustainable Real Estate, 4(1), pp. 78-122, 2012.

[14] Warren-Myers, G., The value of sustainability in real estate: a review from a valuation perspective. Journal of property Investment \& Finance, 30(2), pp. 115-144, 2012.

[15] Bienert, S., Wagger, C. \& Steixner, D., Models to evaluate the quantitative effects of climate change on real estate markets - A first look at approaches and effects. Kuala Lumpur, Pacific Rim Real Estate Society, 2008.

[16] Hennecke, W., Greve, C., Cowell, P. \& Thom, B., GIS-based coastal behaviour modelling and simulation of potential land and property loss: Implications of sea-level rise at Collaroy/Narrabeen Beach, Sydney (Australia). Coastal Management, 32, pp. 449-470, 2004.

[17] Appraisal Institute, The Appraisal of Real Estate. 13th ed. Illinois: The Appraisal Institute, 2008.

[18] Betts, R. M. \& Ely, S. J., Basic Real Estate Appraisal. 6th ed. Mason, Ohio: Thomson South-Western, 2005.

[19] Ratcliff, R. U., Ratcliff Readings on Appraisal and its Foundation Economics. Madison, Wisconsin: Landmark Research, 1979.

[20] Kummerow, M., Theory for Real Estate Valuation: an Alternative Way to Teach Real Estate Price Estimation Methods. Perth: research monograph, Department of Land Economics and Valuation, Curtin University, 2003.

[21] Rudman, P.J., The effects of global warming on maize production: A case study based on climatic data for Vereeniging, Gauteng, South Africa. Unpublished Masters Dissertation. University of Johannesburg, 2007.

[22] Nicholls, R.J., Wong, P.P., Burkett, V.R., Codignotto, J.E., Hay, J.E., McLean R.F., Ragoonaden, S. \& Woodroffe, C.D., Coastal systems and low-lying areas. Climate Change 2007: Impacts, Adaptation and Vulnerability. Contribution of Working Group II to the Fourth Assessment Report of the Intergovernmental Panel on Climate Change, Cambridge, UK: Cambridge University Press, 2007.

[23] Theron, A. \& Rossouw, M., Analysis of potential coastal zone climate change impacts and possible response options in the southern African region. Pretoria, 2nd CSIR Biennial Conference, 2008. 
[24] Umvoto Africa, Sea level rise and flood risk assessment for a select disaster prone area along the Western Cape coast, Cape Town: Provincial Government of the Western Cape Department of Environmental Affairs and Development r: Strategic Environmental Management, 2010.

[25] Heberger, M., Cooley, H., Herrera, P., Gleick, P.H. \& Moore, E., The impacts of sea-level rise on the California coast, s.1.: California Climate Change Center, 2009.

[26] King, P., McGregor, A. \& Whittet, J., The economic costs of sea-level rise to California beach communities, San Francisco: California Department of Boating and Waterways \& san Francisco State University, 2010.

[27] International Valuation Standards Committee, International Valuation Standards. 7 ed. London: International Valuation Standards Committee, 2005.

[28] International Accounting Standards Board, International Financial Reporting Standard 13 Fair Value Measurement, s.1.: International Accounting Standards Board, 2011.

[29] South Africa, Local Government: Municipal Property Rates Act No. 6. Pretoria: Government Printer, 2004.

[30] Jupp, V., The Sage Dictionary of Social Research Methods. London: SAGE Publications, 2006.

[31] South Africa, South African Risk and Vulnerability Atlas, 2010.

[32] Cooper, D.R. \& Schindler, P.S., Business Research Methods. 10th ed. Boston: McGraw Hill, 2008.

[33] Henning, E., van Rensburg, W. \& Smit, B., 2004. Finding Your Way in Qualitative Research. 1st ed. Pretoria: Van Schaik Publishers, 2004.

[34] South Africa, Deeds Registries Act 47 of 1937 as amended. Pretoria: Government Printer, 1937. 